\title{
Effectiveness of Organic Materials as Media in Sulfate Reducing Bacteria Inoculum to Changes on Acid Sulfate Soils
}

\author{
Mazlina $^{1,2}$, Asmarlaili S Hanafiah ${ }^{3}$, A Rauf ${ }^{3}$, Edy Sigit Sutarta ${ }^{3}$ \\ ${ }^{1}$ Doctoral Program of Agricultural Sciences, Faculty of Agriculture, Universitas Sumatera Utara, Medan, Indonesia \\ ${ }^{2}$ Lecture in Faculty of Agriculture, Amir Hamzah University, Medan, Indonesia \\ ${ }^{3}$ Department of Agrotechnology, Faculty of Agriculture, Universitas Sumatera Utara, Medan, Indonesia \\ *Corresponding Author : mazlina_madjid@yahoo.co.id
}

\begin{abstract}
Manuscript received 20 Oct 2021; revised 1 Nov 2021; accepted 10 Nov 2021. Date of publication 10 Jan 2022

Acid sulphate soils (ASS) had low pH, low nutrients availability and also soluble aluminium and iron were high. Inoculum of sulphate reducing bacteria $(\mathrm{SRB})$ which organic matter as media could increased the soil $\mathrm{pH}$, nutrient content and decrease sulfur-total of acid sulfate soils. The research was conducted in a randomized block design with two replications. This study used a randomized block design with two factors and two replications. The first factor was compost inoculum (C) was taken ten treatments from without any inoculum SRB and 9 treatment with different types and dosages of organic matter as media. The second factor was the water content condition (K) namely of K1: $100 \%$ field capacity and K2: $110 \%$ field capacity. Different types and dosages of organic matter appear to influence the changes in soil properties (tends to decrease soil sulfate and increase soil $\mathrm{pH}$, and nutrient content levels in soil and plant). Inoculum $\mathrm{SRB}$ of palm oil empty bunches and weed gave a higher sulfate reduction compared to $\mathrm{C} 0$ (without inoculums) or inoculums with carrier media that used rice straw in water content $100 \%$ or $110 \%$ field capacity (FC).
\end{abstract}

Keywords: Acid Sulfate Soil, Compost, Inoculum, Sulfate Reducing Bacteria.

\section{Introduction}

Acid sulfate soils are sporadically spread throughout the coastal line around the world. The soils are characterized by the presence of pyrite $\left(\mathrm{FeS}_{2}\right)$, which is associated with high acidity, $\mathrm{Al}$ and $\mathrm{Fe}$ content, resulting from its oxidation upon exposure to the atmosphere [1]. One of the effective ways to increase the $\mathrm{pH}$ of acid sulfate soil is through the use of microorganism which can be used to remediate [2]. At present many microorganisms have been utilized to reduce acidity of soils. One of microorganism which could be used to remediate acidic soil and planting media for plants was the sulfate-reducing bacteria (SRB) [3]. These bacteria could be used to reduce soil acidity because they had the ability to reduce sulfate into sulfur which then reacts with metals such as copper, iron, and zinc, to form not soluble and decreased soil fertility due to loss of soil bases, so that the soil experiences P, K, Ca and Mg deficiency [4] [5]. High soil acidity leads to vulnerability to chemical fertilizers as a potential nutrient source, so that their use can be reduced by the use of superior and adaptive microbial fertilizers and organic fertilizer from agricultural waste. The provision of organic material from different compost materials determines how quickly the supply of nutrients. Organic matter can act as a source of organic acids that can control the solubility of metals in the soil or act as a source of nutrients for plants. Organic acids found in organic matter are capable of igniting toxic substances in the soil so that they are not harmful to plants [6]. Organic acids could reduce the amount of phosphate fixed by Fe and $\mathrm{Al}$ through the mechanism of binding so that $\mathrm{P}$ is available to plants [7] [8]. Organic matter could also improve the physical properties of the soil by being able to retain water so that the soil remains wet and can suppress pyrite oxidation [9] [10].

\section{Literature Review}

The use of organic material in acid sulfate soils was carried out with due regard to its quality, source, and availability. Several natural sources of organic materials serving as electron donors and carbon sources have been already investigated: molasses, bagasse, sewage sludge, leaf mulch, wood chips, animal manure, vegetal compost, sawdust, mushroom compost, whey, and other agricultural wastes [11] [12] [13] [14]. The SRB generally need a simple carbon compounds such as organic acids or alcohol to provide as electron donors to Copyright $($ ) Authors. This is an open access article distributed under the Creative Commons Attribution License, which permits unrestricted use, distribution, and reproduction in any medium, provided the original work is properly cited. 
reduce sulfate, although there are some able to use hydrogen [15]. Showed that SRB cultured using organic matter from brain media as inoculum was effective increased $\mathrm{pH}$ and sulfate levels in bioremediation of acid sulfate soils. So this study aims to determine the effectiveness inoculum of SRB which organic matter else as carrier media of the SRB to increase the soil $\mathrm{pH}$ and decrease sulfur-total of acid sulfate soils and also to increase nutrient availability [16] [17] [18].

\section{Methods}

The material used was acid sulfate soil samples taken in the plantation area of PT. Mopoli Raya in composite at a depth of 0-20 $\mathrm{cm}$ as planting media. Experimental study used two factors in the group random design with ten treatments for bacteria inoculum which given Palm Oil empty fruit bunches (PO), Straw and Weeds as material to be composted and used as a carrier media, isolates SRB as sulfate-reducing microbes, Postgate media as specific growth media for SRB, corn plants as indicator plants, This study used a randomized block design (RBD) with two factors and two replications. The first factor was Compost Inoculum (C) of C0 : Control (without any inoculum), C1: inoculum of PO compost (10 ton/ha), C2 : Inoculum of PO compost (30 ton/ha), C3: inoculum of PO compost (45 ton/ha), C4: Inoculum of straw compost (15 tons/ha), C5 : Inoculum of straw compost (30 tons/ha), C6: Inoculum of straw compost (45 tons/ha), C7: Inoculum of weed compost (15 tons/ha), C8: Inoculum of weed compost (30 tons/ha), C9: Inoculum of Weed compost (45 tons/ha), while the second factor was the Water Content Condition (K) is K1: 100\% FC and K2 : 110\% FC. SRB isolates used were superior isolates that can reduce sulfate and increase $\mathrm{pH}$ in acid sulfate soils from previous studies (Sahar $\mathrm{H} \mathrm{A}$, et all, 2016). Isolate SRB was applied as much as $10 \%$ of compost weigh. Then incubated at $\pm 35^{\circ} \mathrm{C}$ for $4-7$ days in an incubator until bacteria grow which were marked by the formation of bubbles on the surface of the compost. After that, the compost inoculum was ready for use then put into the planting medium according to the compost dose that has been determined according to treatment. The compost inoculum was placed in the middle of polybag or right in the planting hole and incubated for 7 days Watering was carried out every afternoon based on $100 \%$ and $110 \%$ FC.

\section{Results and Discussion}

\subsection{Soil $\mathrm{pH}$ and Sulfate levels}

The provision of SRB in inoculums with organic matter tended to increase soil $\mathrm{pH}$ and decrease soil sulfate levels. Different types and dosages of organic matter appear to influence the changes in soil properties. The type of organic material used as SRB carrier media from empty bunches of Palm Oil (PO) and Weeds give a higher sulfate reduction compared to C0 (without inoculums) or inoculums with carrier media that used rice straw in water content $100 \%$ or $110 \%$ FC. The highest soil $\mathrm{pH}$ for various combination treatments was obtained for C8 (Inoculum of Weeds 30 ton/ha), with a pH value of 3,37 in 100\% FC water content and 3,49 in 110\% FC Water content, followed by C3 (Inoculum of PO 45 ton/Ha (Table 1).

Table 1. Average $\mathrm{pH}$ and Soil Sulfate Levels by Providing SRB Inoculums under different water content conditions

\begin{tabular}{lcccc} 
Treatment & $\begin{array}{c}\text { Water content Condition } \\
(100 \% \text { FC })\end{array}$ & $\begin{array}{c}\text { Water content Condition } \\
(110 \% \text { FC })\end{array}$ \\
\hline & $\mathrm{pH}$ & Sulfate levels & $\mathrm{pH}$ & Sulfate levels \\
\hline C0 (Control) & 3,20 & $125,50 \mathrm{c}$ & 3,18 & $277,00 \mathrm{~d}$ \\
\hline C1 (Inoculum of PO 15 ton/ha) & 3.30 & $99,50 \mathrm{ab}$ & 3.26 & $103,00 \mathrm{c}$ \\
\hline C2 (Inoculum of PO 30 ton/ha) & 3.25 & $83,00 \mathrm{~b}$ & 3.22 & $70,50 \mathrm{a}$ \\
\hline C3 (Inoculum of PO 45 ton/ha) & 3.36 & $92,50 \mathrm{ab}$ & 3.39 & $92.50 \mathrm{ab}$ \\
\hline C4 (Inoculum of straws 15 ton/ha) & 3.32 & $84.00 \mathrm{~b}$ & 3,29 & $246.00 \mathrm{~d}$ \\
\hline C5 (Inoculum of straws 30 ton/ha) & 3.32 & $85.00 \mathrm{~b}$ & 3.32 & $106.00 \mathrm{c}$ \\
\hline C6 (Inoculum Straws 45 ton/ha) & 3.22 & $94.00 \mathrm{ab}$ & 3.27 & $99.00 \mathrm{ab}$ \\
\hline C7 (Inoculum of Weeds 15 ton/ha) & 3.22 & $124.50 \mathrm{c}$ & 3.19 & $125.50 \mathrm{c}$ \\
\hline C8 (Inoculum of Weeds 30 ton/ha) & 3,37 & $70.50 \mathrm{a}$ & 3,49 & $62.50 \mathrm{a}$ \\
\hline C9 (Inoculum of Weeds 45 ton/ha) & 3,36 & $72.50 \mathrm{a}$ & 3,34 & $79,00 \mathrm{a}$ \\
\hline Average & 3,26 & 98,3 & 3,28 & \\
\hline
\end{tabular}

The difference in water content conditions at $110 \%$ of the field capacity gave a better influence on the reduction of soil sulfate levels, which will indirectly affect the increase in soil pH. Sulfate levels were lowest in C8 (inoculum of Weeds 30 ton/ha) but not significantly different from $\mathrm{C} 9$ and $\mathrm{C} 2$ and it was significantly differenced with control. In anaerobic conditions, SRB oxidizes a simple organic compounds by utilizing sulfates as electron acceptors and producing sulfides and alkalinity. The resulting sulfide could react with dissolved metals to form metal sulfide deposits, because the solubility of most toxic metal sulfides was generally very low and they could increase $\mathrm{pH}$. Showed that sulfate reducing bacteria in anaerobic bioreactors can reduce sulfate, where the sulfate reducing bacteria was able to reduce the sulfate in waste water. Showed that decrease in sulfate concentration will increase soil $\mathrm{pH}$. This happens due to several interrelated processes, namely because of inundation, addition of organic material and SRB activities.

\subsection{Nutrient Content in the Soil}

The provision of organic matter in the inoculum of SRB could tend to increase N, P, K levels in the soil. The type of inoculum of weeds showed higher levels than other treatments, both in $100 \%$ or $110 \% \mathrm{FC}$ water content conditions. The highest nitrogen level due to 30 tons/ha (C7) inoculum of weed compost was $0.210 \%$ in water content condition $100 \%$ FC but not significantly different from the other. While in water content $110 \%$, weed compost inoculums 45 tons/ha (C7) had the highest nitrogen content in the soil that was $0.255 \%$ but not significantly different from C5, C6, C8, and C9. The provision of water content up to $110 \%$ field capacity (K2) could significantly 
increase nitrogen levels in the soil. C9K2 treatment interactions had the highest nitrogen content in the soil about was $0.255 \%$ while C0K1 treatment interactions had the lowest nitrogen content which was $0.086 \%$. In $110 \%$ ground water content, there was not much increasing $\mathrm{N}$ content in the soil compared to controls. This was be caused by the an aerobic conditions in the soils with a high water table that could reduce emissions by lowering the $\mathrm{N}$ content of the harvested material. In high water content, levels $\mathrm{N}$ content in the plant decreased [19] [20].

The provision of organic matter in the inoculum of SRB could significantly increase P levels in the soil. Both of water content condition of $100 \%$ and $110 \%$ respectively, there were positive correlations between the treatments and the $\mathrm{P}$ (Table 2 and 3 ). The highest phosphate level in water content $100 \%$ FC due to C6 (Inoculum of a straw) was about 49,58 and significantly different from the other. But in water content $110 \%$ FC, the highest phosphate level due to C8 (Inoculum of weeds) was 45,69 and significantly different from C0, C1, C2, C3, C4, C5, C6, and C7. The provision of groundwater up to $110 \% \mathrm{KL}$ (K2) could increase phosphate levels in the soil. The C8K2 treatment interaction had the highest phosphate content in the soil which was $49.58 \mathrm{ppm}$ but it was not significantly different from C8K1 whereas the COK1 treatment interaction had the lowest phosphate content in the soil which was 2.67.

Table 2. Effect of Inoculum of SRB with organic matter as carrier addition on N, P, K, Fe and Mn Content Soil in Water content condition $100 \%$ FC

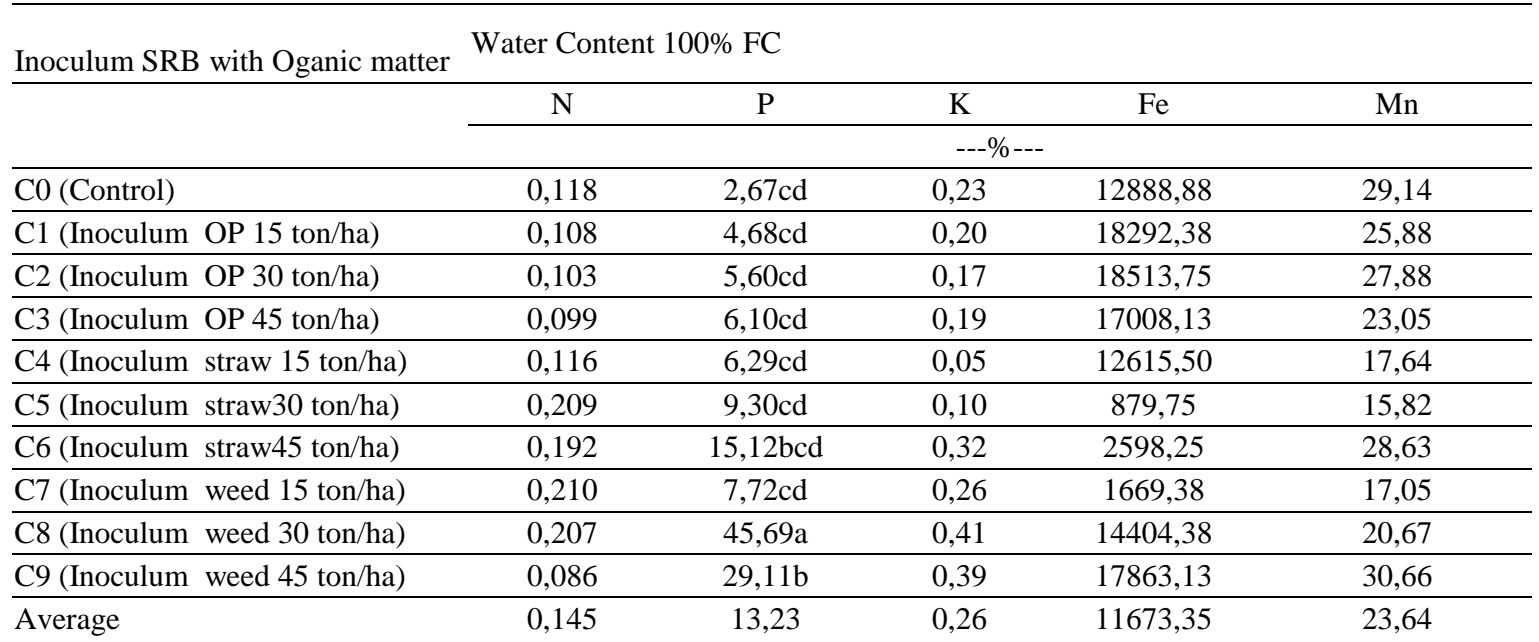

Weed compost inoculum 30 tons/ha (C8) had the highest levels of potassium in the soil that was $0.45 \%$. The lowest potassium levels were found out due to the treatment 15 tons/ha straw compost inoculum (C4) which is $0.07 \%$. The provision of water content up to $110 \%$ of field capacity $(\mathrm{K} 2)$ tended to reduce potassium levels in the soil. C8K2 treatment interactions have the highest potassium content in the soil that was $0.49 \%$ while $\mathrm{C} 4 \mathrm{~K} 1$ treatment interactions had the lowest potassium content in the soil was $0.05 \%$.

The provision of organic matter in the inoculum of SRB could tend to decrease Fe and Mn levels in the soil. In water content condition $100 \%$ FC, giving of SRB inoculum straw compost in 30 tons/ha (C5) showed the lowest decrease in Fe and Mn levels was 879,75 and 15,82 but in $110 \%$ FC water content. SRB inoculum of compost weeds 30 tons/Ha (C8) showed the results of Fe and Mn being the lowes were 11928,13 and 12,74. The inoculum SRB of straw at 100\% FC conditions was faster to release P bonds from AL and Fe or Mn caused it had $\mathrm{C} / \mathrm{N}$ which was faster mineralized than SRB inoculum with Palm Oil empty fruit bunches or Weeds.

SRB inoculum with weeds and PO compost as a subtrat media was decompossed more longer time giving high reduce alot of iron and mangan concentrations and that would be more higher increased availablity phosphate ions in soil solution. Decreasing Fe and Mn ions would increasing interchangeable bases in the cation exchange complex in the soil and $\mathrm{P}, \mathrm{K}, \mathrm{Ca}$, and $\mathrm{Mg}$ increased.

Table 3. Effect of Inoculum of SRB with organic matter as carrier addition on N, P, K, Fe and Mn Content of Soil in water content condition $110 \%$ FC

\begin{tabular}{lccccc}
\hline Inoculum of SRB in compost & \multicolumn{5}{c}{ Water Content 110\% FC } \\
\cline { 2 - 6 } & $\mathrm{N}$ & $\mathrm{P}$ & $\mathrm{K}$ & $\mathrm{Fe}$ & $\mathrm{Mn}$ \\
\cline { 2 - 6 } & \multicolumn{5}{c}{ Nutrient Content in soil (\%) } \\
\hline C0 (Control) & 0,110 & $2,98 \mathrm{~d}$ & 0,15 & 71777,38 & 18,16 \\
\hline C1 (Inoculum OP 15 ton/ha) & 0,115 & $3,77 \mathrm{~cd}$ & 0,21 & 87148,88 & 81,73 \\
\hline C2 (Inoculum OP 30 ton/ha) & 0,115 & $13,18 \mathrm{~cd}$ & 0,28 & 15180,63 & 20,20 \\
\hline C3 (Inoculum OP 45 ton/ha) & 0,111 & $8,10 \mathrm{~cd}$ & 0,19 & 15081,75 & 14,99 \\
\hline C4 (Inoculum straw 15 ton/ha) & 0,109 & $7,09 \mathrm{~cd}$ & 0,08 & 109165,38 & 26,57 \\
\hline C5 (Inoculum straw30 ton/ha) & 0,227 & $29,10 \mathrm{a}$ & 0,27 & 14694,50 & 28,75 \\
\hline C6 (Inoculum straw45 ton/ha) & 0,213 & $49,58 \mathrm{a}$ & 0,44 & 17859,75 & 25,22 \\
\hline C7 (Inoculum weed 15 ton/ha) & 0,228 & $7,41 \mathrm{~cd}$ & 0,32 & 13316,38 & 25,37 \\
\hline C8 (Inoculum weed 30 ton/ha) & 0,228 & $12,13 \mathrm{~cd}$ & 0,49 & 11928,13 & 12,74 \\
\hline C9 (Inoculum weed 45 ton/ha) & 0,255 & $19,87 \mathrm{bc}$ & 0,34 & 17940,25 & 24,24 \\
\hline \multicolumn{1}{c}{ Average } & 0,171 & 15,32 & 0,25 & 31409,30 & 22,79 \\
\hline
\end{tabular}




\subsection{Nutrient levels in the Leaves plant}

The provision of organic matter as a carrier media in the inoculum of SRB could tend to increase nutrient but had not shown a significant effect on N, P, K nutrient levels in plants (Table 4).

Table 4. Effect of Inoculum of SRB with organic matter as carrier addition on N, P and K Content of The Plant in water Content condition $100 \%$ and $110 \%$ FC

\begin{tabular}{lcccccc}
\hline \multirow{2}{*}{ Inoculum of SRB in compost } & \multicolumn{7}{c}{ Nutrient Content in Leaves plant } \\
\cline { 2 - 7 } & \multicolumn{7}{c}{ FC 100\% } & \multicolumn{5}{c}{ FC 110\% } \\
\cline { 2 - 7 } & $\mathrm{N}$ & $\mathrm{P}$ & $\mathrm{K}$ & $\mathrm{N}$ & $\mathrm{P}$ & $\mathrm{K}$ \\
\hline C0 (Control) & 1,99 & 1,85 & 0,93 & 0,50 & 4,08 & 2,39 \\
\hline C1 (Inoculum OP 15 ton/ha) & 1,99 & 1,69 & 1,08 & 1,05 & 3,19 & 4,10 \\
\hline C2 (Inoculum OP 30 ton/ha) & 2,10 & 1,91 & 1,42 & 0,93 & 4,59 & 3,65 \\
\hline C3 (Inoculum OP 45 ton/ha) & 1,49 & 2,03 & 1,02 & 0,88 & 2,68 & 3,71 \\
\hline C4 (Inoculum straw 15 ton/ha) & 2,14 & 1,89 & 0,79 & 0,68 & 2,65 & 3,82 \\
\hline C5 (Inoculum straw30 ton/ha) & 2,09 & 1,72 & 1,14 & 1,35 & 3,99 & 4,38 \\
\hline C6 (Inoculum straw45 ton/ha) & 1,69 & 1,56 & 1,32 & 1,17 & 3,07 & 3,86 \\
\hline C7 (Inoculum weed 15 ton/ha) & 1,76 & 1,97 & 1,08 & 0,92 & 4,28 & 4,35 \\
\hline C8 (Inoculum weed 30 ton/ha) & 1,70 & 1,62 & 0,99 & 0,92 & 3,75 & 4,17 \\
\hline C9 (Inoculum weed 45 ton/ha) & 1,78 & 2,04 & 1,42 & 1,48 & 4,25 & 4,23 \\
\hline Average & 0,14 & 0,17 a & 1,12 & 0,99 & $3,65 \mathrm{~b}$ & 3,86 \\
\hline
\end{tabular}

Content of $\mathrm{N}$ in the plant due withouth SRB with organic matter as media carrier only occurred at water content $100 \% \mathrm{FC}$, whereas at $110 \%$ FC there was a decrease in the plant $\mathrm{N}$ levels. The highest $\mathrm{N}$ levels were found in the treatment $\mathrm{C} 1$ (Inoculum OP 15 ton/ha). Decreased levels of $\mathrm{N}$ in plants caused by the reduction of nitrate reduction into ammonium or the occurrence of denitrification process. It was changed occur from sulphide to achieve nitrogen removal by utotrophic denitrification. The provision of organic matter in the inoculum of SRB can tend significantly increase N, P and K levels in the plant on both of water content condition of $100 \%$ and $1100 \%$. The highest $\mathrm{P}$ and $\mathrm{K}$ levels were found out in treatment C2 (Inoculum OP 30 ton/ha) and C5 (Inoculum straw 30 ton/ha). This is thought to be caused by organic material from $\mathrm{PO}$ which could increased $\mathrm{pH}$ and $\mathrm{P}, \mathrm{K}$ increase in the soil so that it is available for plants. Organic ingredients could provide enormous benefits. It can be a source of nutrients N, P, K, and others, increasing soil CEC, reducing, increasing and improving soil aggregation and soil moisture, ethoxification of $\mathrm{Al}$ and increase soil biodiversity. This is in accordance with research, which states that the application of Palm oil of empty bunches could increase nutrient content and also reduce al in the soil that can improve P uptake of nutrients and reduce Al-dd

\section{Conclusion}

Acid sulfate soils are dominated by sulfur or oxidizing-reducing bacteria. These soils may also contain some beneficial microorganisms that help improve plant growth. In this study, it was found that the $\mathrm{pH}$ of the acid sulfate soils was very low and, especially at the depth below $50 \mathrm{~cm}$, proving that these were true acid sulfate soils. In these research showed the provision of superior SRB isolates in acid sulfate soil media planted with corn as an indicator plant showed a change in the chemical properties of the soil, especially towards the increase in $\mathrm{pH}$, the content of $\mathrm{P}, \mathrm{K}$ levels in soil and levels of content $\mathrm{N}, \mathrm{P}, \mathrm{K}$ in plants. The increase in $\mathrm{pH}$ and nutrient availability was caused by the reduction of sulfate, Fe and $\mathrm{Mn}$ content of the soil. An increase in soil $\mathrm{pH}$ value reflects an increase in soil fertility so that plant growth will increase. Provision of water content up to $110 \% \mathrm{KL}$ affects the availability of oxygen in the soil. In the research showed that $\mathrm{Fe}$ and $\mathrm{Mn}$ content had decreased, So both could be increasing $\mathrm{pH}$. If sulfate-reducing bacteria use sulfate as an electron acceptor, iron-reducing bacteria use iron (III) as a terminal electron acceptor. The other results from the use of sulfate-reducing bacteria will reduce the solubility of heavy metals, especially Fe, Mn and Al. Also add that SRB can be applied to reduce environmental pollution, as little as possible decontaminate sulfate and reduce metal concentrations ( $\mathrm{Fe}, \mathrm{Mn}, \mathrm{Al})$ through the process of metal deposition. In the acid sulfate soil that is inundated, the soil will be more stable and the $\mathrm{pH}$ will tend to be neutral so that the acidic $\mathrm{pH}$ of the soil-bound by $\mathrm{Al}$ and $\mathrm{Fe}$ is gradually released and available to plants. Which states that in nature, SRB often associates in carrying out environmental bioremediation under anaerobic conditions, sulfate-reducing bacteria (SRB) utilize sulfate to oxid carbon sources for SRB are usually low molecular weight compounds such as $\mathrm{H}_{2}$, organic acids ize organic compounds and generate sulfide (S2-). In these research also showed that the provision of superior SRB isolates tended to increase the $\mathrm{pH}, \mathrm{N}, \mathrm{P}, \mathrm{K}$ and decreased Sulfate, Fe and Mn content was planted by media inoculum of Weed and Palm oil compost.Inoculum of weed and palm oil had carbon sources low molecular weight compounds. Preferred carbon sources for SRB usually low molecular weight compounds such as $\mathrm{H} 2 \mathrm{eg}$, formic acid, propionate, maleic) and volatile organic acids and alcohols, e.g., methanol, ethanol. Several natural sources of organic materials serving as electron donors and carbon sources have been already investigated: molasses, bagasse, sewage sludge, leaf mulch, wood chips, animal manure, vegetal compost, sawdust, mushroom compost, whey, and other agricultural wastes. In conclusion, provision of inoculums SRB with organic matter tended to decrease soil sulfate and increased soil $\mathrm{pH}$, and nutrient content levels in soil and plant. Different types and dosages of organic matter appear to influence changes in soil properties. The type of organic matter used as SRB carrier media of empty bunches of Palm Oil and Weed gave a higher sulfate reduction compare to C0 (without inoculums).The potential of these SRB should be exploited further for the sustainable management of acid sulfate soils. For instance, they could be used as bio-fertilizers to improve the fertility of acid sulfate soils. 


\section{References}

[1] M. Dass, "Cosmopolitanism and the Unfollowable Routines and Rituals in Ishtiyaq Shukri's The Silent Minaret," J. Lit. Stud., vol. 33, no. 1, 2017, doi: 10.1080/02564718.2017.1290382.

[2] M. A. Shamshuddin, F. Rojas, R. Cardenas, J. Pereda, M. Diaz, and R. Kennel, "Solid state transformers: Concepts, classification, and control," Energies, vol. 13, no. 9. 2020, doi: 10.3390/en13092319.

[3] L. Mäkinen, S. Loukusa, and S. Kunnari, "Tyypillisesti kehittyneiden lasten ja lasten, joilla on kielellinen erityisvaikeus tai autismikirjon häiriö, suoriutuminen Edmonton Narrative Norms Instrument (ENNI) -kerrontatestissä,” Puhe ja kieli, no. 1, 2018, doi: $10.23997 /$ pk.65950.

[4] A. Dariah, E. Susanti, and F. Agus, "Simpanan Karbon dan Emisi CO2 Lahan Gambut," Pengelolaan Lahan Gambut Berkelanjutan, vol. 1, 2011.

[5] A. Dariah et al., "KARAKTERISTIK LAHAN GAMBUT Sifat Fisik Tanah Gambut Kematangan Gambut," Balai Penelit. Tanah, Bogor, 2013.

[6] P. Balazs and H. Harbrecht, "Frames for the Solution of Operator Equations in Hilbert Spaces with Fixed Dual Pairing," Numer. Funct. Anal. Optim., vol. 40, no. 1, 2019, doi: 10.1080/01630563.2018.1495232.

[7] B. Javaheri et al., "Rubio D: Spontaneous human adult stem cell transformation. Cancer Res. 65 (8): 3035-9. 2005 Apr 15," J. Bone Miner. Res., vol. 7, no. 1, 2011.

[8] D. Maisa Putra, O. Oktamianiza, M. Yuniar, and W. Fadhila, "Study Literature Review On Returning Medical Record Documents Using HOT-FIT Method,” Int. J. Eng. Sci. Inf. Technol., vol. 1, no. 1, 2021, doi: 10.52088/ijesty.v1i1.102.

[9] M. H. B. Hayes and R. S. Swift, "An appreciation of the contribution of Frank Stevenson to the advancement of studies of soil organic matter and humic substances," J. Soils Sediments, vol. 18, no. 4, 2018, doi: 10.1007/s11368-016-1636-6.

[10] S. Romadhona, F. Kurniawan, and J. Tistogondo, "Project Scheduling Analysis Using the Precedence Diagram Method (PDM) Case Study: Surabaya's City Outer East Ring Road Construction Project (Segment 1),” Int. J. Eng. Sci. Inf. Technol., vol. 1, no. 2, 2021, doi: 10.52088/ijesty.v1i2.56.

[11] Y. M. Coetser, "Cruel Art: Intersections between Art, Animals, and Morality," arte, vol. 55, no. 1, 2020, doi: 10.1080/00043389.2019.1643072.

[12] C. A. Nascimento, "O preto no branco: memória, identidade e resistência na poesia afrobrasileira de Cuti," Nau Literária, vol. 16, no. 1 , 2020, doi: 10.22456/1981-4526.104957.

[13] A. P. Annachhatre and S. Suktrakoolvait, "Biological sulfide oxidation in a fluidized bed reactor," Environ. Technol. (United Kingdom), vol. 22, no. 6, 2001, doi: 10.1080/09593332208618238.

[14] K. R. Waybrant, D. W. Blowes, and C. J. Ptacek, "Selection of reactive mixtures for use in permeable reactive walls for treatment of mine drainage," Environ. Sci. Technol., vol. 32, no. 13, 1998, doi: 10.1021/es9703335.

[15] T. Wang, K. Y. Wu, R. C. Miner, J. M. Renaud, R. S. B. Beanlands, and R. A. deKemp, "Reproducible quantification of cardiac sympathetic innervation using graphical modeling of carbon-11-meta-hydroxyephedrine kinetics with dynamic PET-CT imaging," EJNMMI Res., vol. 8, 2018, doi: 10.1186/s13550-018-0421-5.

[16] N. A. S. Taufieq, A. R. Sahibin, H. Jamil, Huyyirnah, and A. Arfan, "Isolation and Identification of Desulfovibrio sp . Bacteria from Acid Sulfate Soil," Asian J. Appl. Sci., vol. 03, no. 05, 2015.

[17] N. A. S. Taufieq, N. Pertiwi, and I. A. Ahmad, "Properties of Concrete Blocks Made from Sugar Mill Waste," in Journal of Physics: Conference Series, 2019, vol. 1244, no. 1, doi: 10.1088/1742-6596/1244/1/012014.

[18] M. Natsir Abduh, N. Pertiwi, and N. A. S. Taufieq, "The Effect of Rice Husk Ash and Sulfatic Acid Solutions on the Setting Time and Compressive Strength of Mortar," in Journal of Physics: Conference Series, 2019, vol. 1244, no. 1, doi: 10.1088/1742$6596 / 1244 / 1 / 012046$.

[19] H. Baños, "Identifying Species Network Features from Gene Tree Quartets Under the Coalescent Model," Bull. Math. Biol., vol. 81, no. 2, 2019, doi: 10.1007/s11538-018-0485-4.

[20] S. Kumari and A. Harikrishnan, "Importance of Financial literacy For Sustainable Future Environment: A Research Among People In Rural Areas With Special Reference To Mandi District,Himachal Pradesh,” Int. J. Eng. Sci. Inf. Technol., vol. 1, no. 1, 2021, doi: 10.52088/ijesty.v1i1.36. 